Proceeding

\title{
Immunotherapy in lung cancer
}

\section{Proceeding}

An important part of the immune system is its ability to by itself prevent the attack on normal cells in the body. To do this, the immune system uses "checkpoints" that are molecules in the immune cells that need to be activated [or deactivated] to initiate an immune response. Sometimes cancer cells use these checkpoints to avoid being attacked by the immune system. New drugs targeting these checkpoints have a promising future as cancer treatments. Currently the main objective in Oncology is to use immunotherapy, which is the use of medicines to stimulate the person's own immune system so that it recognizes and destroys cancer cells more effectively.

Currently the most used in lung cancer are Opdivo and pembrolizumab attack PD-1, a protein in the cells of the immune system called $\mathrm{T}$ cells that normally help prevent these cells from attacking other cells in the body. By blocking PD-1, these drugs reinforce the immune response against cancer cells, which may shrink or slow the growth of some tumors. Atzolizumab attacks PD-L1, a PD-1-related protein found in some tumor cells and immune cells. Blocking this protein can also help stimulate the immune response against cancer cells.

These medicines can be used in people with certain types of nonsmall cell lung cancer, whose cancers begin to grow again after using chemotherapy or other drug treatments. Pembrolizumab can also be used as the first treatment (rather than chemotherapy or other drugs) in some people. These medications are given by intravenous infusion every two to three weeks. The progress of the medicine is remarkable day by day, generating new drugs and new molecular targets to attack tumor cells, thus achieving in the long term, that what can now be terminal cases, are carried to chronicity (Figures $1 \& 2$ ).

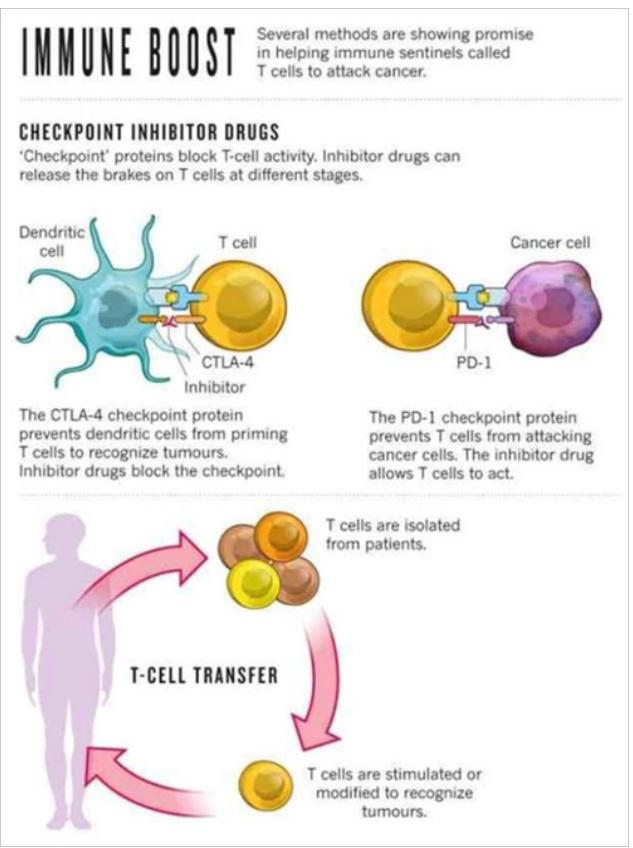

Volume 7 Issue 4 - 2017

\section{Daniela Capdepon}

Centro Oncologico campana, Argentina

Correspondence: Daniela Capdepon, Owner and Medical Director Cancer Center Campana Oncology and Oncohematology Writer and Editor of Jornual, Certified Genetic Counselor,Argentina, Tel 5493489 618997, Email dcapdepon@yahoo.com.ar

Received: February 22, 2017 | Published: February 28, 2017

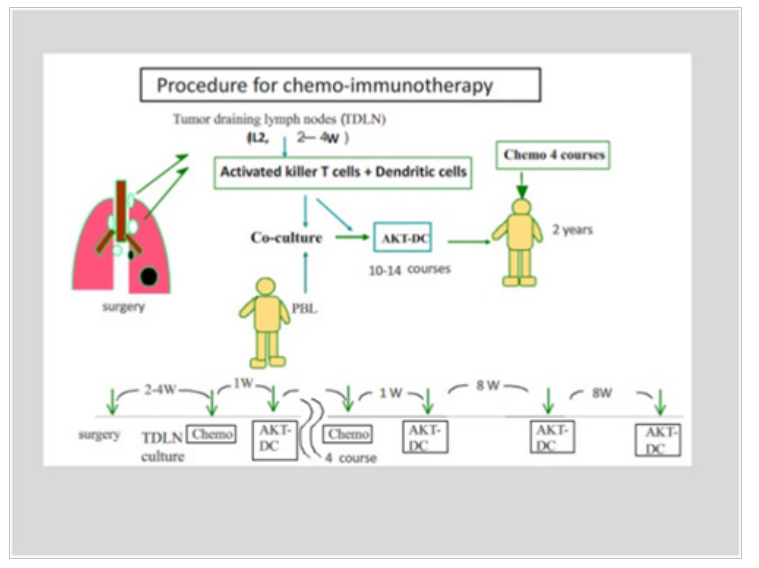

Figure 2 Procedure for chemo-immunotherapy.

\section{Acknowledgments}

None.

\section{Conflicts of interest}

Author declares there are no conflicts of interest.

Figure I Checkpoint inhibitor drugs 